\title{
IMPROVEMENT OF LOW RAINFALL HILL COUNTRY
}

\author{
R. I. BEATTIE* \\ Farmer, Patearoa Station, Maniototo
}

Patearoa Station is situated at the south-east end of the Maniototo plain, and runs from the plains level of 1,200 ft at the homestead to a height of $4,700 \mathrm{ft}$ at the top of the Rock and Pillar range. The station comprises 13,000 acres, 700 acres of which is arable, the balance being hill country.

The general aspect is north-west, and the district enjoys the doubtful privilege of running Alexandra a very close race for the distinction of being the driest in $\mathrm{N}$ ew Zealand. Over the last 10 years, the annual rainfall has been $13.63 \mathrm{in}$. and the 50-year average is just over $14 \mathrm{in}$. per year.

The sheep carried are romney-merino halfbreds and the approximate numbers at the time when the development started were as follows:

\begin{tabular}{|c|c|c|}
\hline Breeding ewes & $\ldots$ & 1,200 \\
\hline Wethers & $\ldots$ & 1,200 \\
\hline Mixed sex hoggets & $\ldots .$. & 700 \\
\hline Rams and killers & $\cdots$ & 100 \\
\hline Total & $\ldots$ & 3,200 \\
\hline
\end{tabular}

The natural aspect of the country and its dryness made it an ideal breeding ground for rabbits. All of the run up to $2,500 \mathrm{ft}$ was heavily infested and consequently the stock were seldom in good condition and production was not high. The average wool clip was round 60 bales, at a weight per head of $61 / 2$ to $7 \mathrm{lb}$. The lambing percentage was usually round 60 and the death rate up to $9 \%$. All surplus stock was sold in store condition.

An area of 25 acres of lucerne for hay and about 40 acres of turnips was the extent of the winter feed'available for the hoggets. Often the turnip crops were very poor because of the dry seasons and the damage by rabbits.

In 1940 it was decided that the only satisfactory way to provide sufficient winter feed was to establish more lucerne 
for hay. A start was made by ploughing an area of flat, alkaline land which adjoined the hay paddock. This soil type was not ideal because of the poor seed strike in the more salty patches, but the better, less alkaline ground produced a healthy and vigorous crop which was able to get its root down to water, and after five years a total area of 100 acres of lucerne had been established.

This area was more than was necessary to provide the hay wanted for winter feed, so 75 acres of the lucerne, together with a run-off of about 100 acres of native river flat and some dry stony ridges, were grazed in the spring. Some 500 ewes could be carried on this area through the lambing until about mid-December when the ewes and lambs were all put out on to the summer run country. After moving the ewes it was possible to cut a good crop of hay off most of the area during February. The autumn growth provided good fresh feed for the weaned lambs towards the end of March,

Because of the success of this grazing and haying development, it was decided that as much as possible of the arable land should be resown with a lucerne and grass mixture for straight-out grazing.

This country is all light and sandy, classed mainly as Drybread shallow sandy loam and Patearoa sandy loam with some Becks clay loam and Pigburn sandy loams. Because of the low rainfall, English grasses sown in the past had had a very short life, surviving only four to five years.

Development of the area was by ploughing blocks of 40 to 50 acres, taking a crop of turnips in the first year, and then sowing out the next season with a turnip, lucerne and grass mixture. Progress was not fast, but was all that could be managed each year without increasing the labour force, which consisted of the writer and one other man.

The seed mixture used is $7 \mathrm{lb}$ of inoculated lucerne and $12 \mathrm{oz}$ of turnip sown through the drill, together with $3 \mathrm{lb}$ of cocksfoot and $1 \mathrm{lb}$ perennial ryegrass broadcast through the grass-seed box. In recent years Blackmore coulters with $31 / 2$ in. centres have been used. Reverted superphosphate at $1 \frac{1 / 4}{4}$ cwt per acre is always used. It was necessary to fit a reduction drive to the seed box, in order to get an even flow of seed at the low seeding rate used. 
By 1956, a further 200 acres of lucerne had been established and all the run-out paddocks had been re-sown. The total area in luderne was now 300 acres.

At this stage the basic stocking pattern had not changed much, the flock numbers being still almost the same as in 1940, but overall production had increased greatly, and at the same time the regeneration taking place on the hill country was quite noticeable.

This regeneration was due mainly to two factors:

(1) The greatly reduced rabbit population, the result of rabbit board control and modern aerial poisoning techniques.

(2) The spelling which the hill country was able to re ceive because of the big increase in carrying capacity of the improved areas around the homestead.

As an indication of the improvement, the wool clip had now risen to 92 bales, at an average weight per head of $91 / 2 \mathrm{lb}$, the lambing percentage was up to 95 and the death rate had dropped to $2 \%$. This increase had been reached gradually and was still improving each year as the general condition of the whole flock improved.

It could perhaps be said that the stocking rate was not being increased quickly enough, but it seemed preferable to be conservative in this matter and to provide for a reserve of feed on the run country to tide over a 'dry spell. In this district drought periods can occur at any time of the year and often last for up to four months with a total rainfall for the period of less than 1 in. Any suggestion of overstocking can therefore be very risky. In retrospect, it also seems evident that the carrying capacity in the late 1930s had probably been much higher than it should have been, considering the bareness of the country and the heavy rabbit infestation.

Today, it is possible to put ewes and lambs out on the run when feed is getting short in the home paddocks, and still draft up to half the cull lambs at weaning time, whereas twenty years ago the tops of the lambs would have been only in store condition.

With the bulk of the ploughable land now improved and a total area of 300 acres of lucerne, the programme was continued by using a chisel plough on the more difficult country amongst the rocks on the lower foothills. A block 
of about 250 acres, of which it was possible to work 170 acres, was developed next and here to speed up progress the worked ground was sown out straight into the turnip and İucerne mixture.

With the help of two good autumn seasons, the results here were spectacular. What was originally bare scabweed country with small areas of tussock on the dark sides of the ridges and a carrying capacity of about 1 ewe to 4 acres, soon blossomed into good green lucerne country, and it is now possible on this block to lamb and carry through to mid-December 300 ewes.

On this light land, where the rock is often only about 6 or 8 in. below the surface, growth falls off quickly in a dry spell. It is necessary to have a reserve block of tussock country available if no useful spring rains occur. In spite of this drawback, these blocks of improved foothill country are invaluable to assist in spelling tussock blocks after oversowing, or just for general regeneration purposes.

This improvement programme has been continued and the total area of land now under lucerne is 620 acres. More small areas can still be brought in, but the rate of increase will slow down because some of the original areas will soon need to be re-sown.

This type of pasture has proved to have a very long life, some paddocks which have been down for 15 to 20 years still producing well. Grass invasion is not a severe problem as the light soils seem unable to support grass through

TABLE 1: PERFORMANCE COMPARISON, 1940 AND 1966

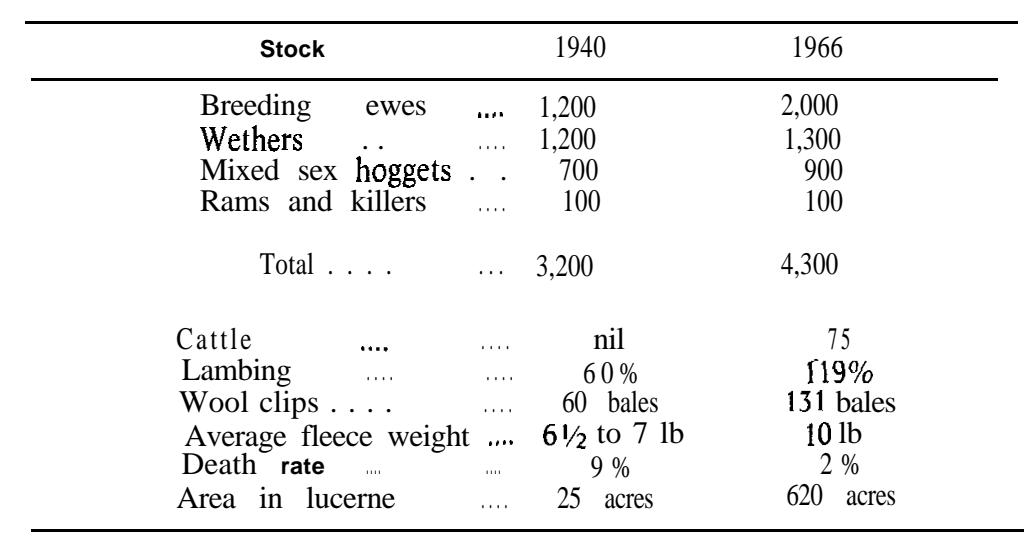


the dry periods. In fact even the cocksfoot largely disappears after four to five years. The only paddocks which have presented a barley-grass problem are the original ones on the alkaline flats, which have all had to be worked up again because of severe infestation by this weed.

To round off the picture of this development programme, the figures given in Table 1 speak for themselves.

It has become necessary to run some cattle on the hill country to keep rough growth in check, and 75 head were wintered this year. Because of the present very dry spring (just over 2 in. of rain since last A pril), it may not be possible to carry all these young cattle right through and it may be necessary to sell some during the summer.

Finally, the development programme has been well worth while both financially and in terms of personal satisfaction and achievement. There are probably large areas throughout Central Otago which could also be developed by the establishment of lucerne and grass for grazing purposes with similar results.

Combined discussion appears on page 139. 